\title{
Współczesne badania produkcji i dystrybucji filmowej - wprowadzenie
}

\author{
Marcin Adamczak \\ Konrad Klejsa
}

1.

Istotną zmianą w pejzażu współczesnych badań filmoznawczych jest ich umocowanie empiryczne oraz nacisk na intersubiektywne rozpoznania. Zmianę tę widać na różnych obszarach refleksji filmoznawczej - zarówno w teorii filmu, w której upowszechniają się matematyczne procedury analizy oraz właściwe neuronaukom eksperymenty dotyczące percypowania komunikatów audiowizualnych, jak i w badaniach historycznych, wspieranych przez prace archiwistyczne czy wywiady. Zmiana ma charakter systemowy - dotyczy zarówno metody (odejście od hermeneutycznych interpretacji i efektownych hipotez), jak i samego przedmiotu: nie jest już nim tylko gotowe dzieło filmowe i jego twórca, lecz dynamicznie pojmowany proces wytwarzania, rozpowszechniania oraz doświadczania kultury filmowej.

Wspólnym mianownikiem tych badań jest kategoria ,poza ekranem”, wprowadzona do slangu filmoznawczego przez Edwarda Zajička. Bywa ona najczęściej rozumiana w kategoriach metaforycznych, pozwalających na potraktowanie ,ppozaekranowości” jako całej maszynerii produkcji filmowej: polityki państwa, aspektów prawa (pracy, własności intelektualnej, nawet BHP!), ekonomii i zarządzania. A przecież należałoby zapytać także o tych, którzy pracują o b o k ekranu (całkiem dosłownie, bo w przestrzeniach do niego przyległych): o właścicieli kin, kinooperatorów (zawód ginący!), bileterów, pracowników działów sprzedaży... W każdym wypadku w grę wchodzi ludzki wysiłek wymagający większych lub mniejszych kompetencji, ale zawsze warunkowany istnieniem kultury filmowej (i kulturę tę współtworzący). Skrzywi się ten i ów: przecież tego typu badania to domena socjologów, specjalistów od zarządzania, badaczy z dziedziny nauk społecznych. Nic bardziej mylnego - filmoznawstwo dawno przestało być dyscypliną stricte humanistyczną (zresztą, czy takie w ogóle istnieją?), a to, co „społeczne” w kulturze filmowej nie wyczerpuje się w opracowaniach dotyczących reprezentacji - obrazów filmowych takiej czy innej grupy, bowiem obrazy te są wytwarzane w konkretnych uwarunkowaniach politycznych, ekonomicznych i kulturowych.

Oddawany do rąk Czytelników tom zawiera prace prezentujące dwa pokrewne podejścia: badania produkcyjne i badania dystrybucji. Ponieważ nurty te od kilkunastu już lat rozwijają się na Zachodzie, zyskały dojrzałość pozwalającą widzieć je nie tyle w prostej opozycji do ujęć tekstualnych, jako ich tło lub mało istotne uzupełnienie, ile w sposób podkreślający komplementarność obu tradycji badaw- 
czych. Podejścia te od niedawna torują sobie drogę w rodzimym filmoznawstwie, czego dowodem są także projekty badawcze kierowane przez autorów koncepcji tego numeru ${ }^{1}$. W publikacjach będących ich pokłosiem zawarto podstawowe informacje o metodach oraz dorobku badań produkcyjnych i dystrybucyjnych ${ }^{2}$; w niniejszym tekście uzupełniamy je o wątki nowe bądź wcześniej pominięte lub jedynie zasygnalizowane.

2.

W ostatnich latach, przede wszystkim dzięki pracom Johna T. Caldwella, Mirandy Banks czy Vicki Mayer, a także badaczy europejskich - Petra Szczepanika czy Patricka Vonderau, badania produkcyjne dobrze osadziły się w świecie akademii. Mają jednak wciąż potencjał rozwoju i trudno się oprzeć wrażeniu, że ciągle znajdujemy się na etapie „przedteoretycznym” subdyscypliny, która czeka jeszcze na swoje kluczowe prace. Szczególnie istotna jest tu potrzeba mocniejszej systematyzacji i uteoretycznienia badań. Grozi im bowiem osunięcie się ku statusowi zbioru oderwanych od siebie „studiów przypadku” o wąskim przedmiotowym oraz czasowym zakresie analizowanego obszaru. W nauce niekiedy nie warto jednak przyśpieszać biegu wypadków, być może wciąż konieczne jest dopełnienie studiów cząstkowych i maksymalna eksploracja granic badań produkcyjnych (geograficznych, historycznych, gatunkowych), by dokonać większego uteoretycznienia; niewykluczone, że wiodącego przez etap komparatystyczny. Uderzające jest jednak, że posługując się tak często wyrażeniem „kultura produkcji”, niewiele uwagi poświęcamy samemu słowu „kultura”, jej rozumieniu oraz pytaniu, jak przejawiałyby się różne kultury produkcji filmowej oraz ich wpływ na tekstualny wymiar filmów.

Badania produkcyjne, mające wielu XX-wiecznych prekursorów (Hortense Powdermaker, Leo Rosten czy znacznie później Thomas Schatz i Janet Wasko, a na gruncie rodzimym Edward Zajiček), bujnie rozwinęły się w ostatnich latach dzięki młodszemu pokoleniu badaczy. W centrum ich zainteresowań sytuuje się refleksja nad procesem wytwarzania dzieł audiowizualnych jako złożonym zjawiskiem społecznym. W ujęciu badaczy produkcji tak zdecydowanie konkurujące w ubiegłym stuleciu paradygmaty Wielkich Teorii oraz szkoły z Wisconsin miały w istocie wiele wspólnego. Polegały bowiem na traktowaniu filmu jako „czarnej skrzynki”, której zapis badacze starali się zrekonstruować, posługując się swoimi narzędziami analizy (strukturalnymi, poststrukturalnymi, neomarksistowskimi, semiotycznymi, psychoanalitycznymi, feministycznymi bądź neoformalnymi). Tymczasem dla badaczy produkcji istotne jest rozciągnięcie obszaru zainteresowań na to, co poprzedza powstanie artefaktu, jakim jest film.

Refleksja filmoznawcza zostaje tym samym rozszerzona o nowe terytoria i metody badawcze, najczęściej czerpane z nauk społecznych. Z dziedziny historii wywodzą się skrupulatne kwerendy archiwalne (wiążące się z dowartościowaniem pisania historii kina na podstawie archiwalnych dokumentów, nie zaś interpretacji dzieł oraz impresji na temat reżyserujących je twórców). Z nauk politycznych i ekonomicznych pochodzą wzorce analiz instytucji, strumienie finansowania, biurokratycznych procedur oceny wniosków, badania budżetów i statystyk rynkowych. Socjologia natomiast inspiruje do zainteresowania realiami zbiorowego procesu twórczego z mnogością zaangażowanych aktorów, szczególnie badania jakościowe skłaniają do obserwacji uczestniczącej i uprawiania etnografii planu filmowego. 
Dogodnym narzędziem opisu skomplikowanego uniwersum produkcji okazała się teoria Aktora-Sieci, pozwalająca usystematyzować chaos produkcyjnego świata przez wykazanie czterech współkształtujących go i wchodzących ze sobą w interakcje czynników: technologii, finansów, tekstów i ludzi.

Badania produkcyjne rozszerzyły horyzont filmoznawstwa oraz paletę jego narzędzi metodologicznych (o wywiady pogłębione prowadzone już nie tylko z reżyserami, lecz także wieloma innymi pracownikami pionów niższego szczebla; badania archiwalne już nie tylko scenariuszy, lecz także kalendarzówek, planów pracy, ocen ekspertów czy stenogramów z narad; o statystyczne badania rynku i widowni oraz etnograficzną obserwację procesu wytwarzania dzieła filmowego). Badania produkcyjne zatem ,zaludniły” świat opisów filmoznawczych znacznie większą niż wcześniej rzeszą ludzkich i nie-ludzkich aktorów (w socjologicznym rozumieniu tego terminu) oraz wzbogaciły go o więcej ,gatunków” pisarskich niż monografia reżysera, kina narodowego, gatunku bądź stylu.

W literaturze przedmiotu wyraźnie rysują się dwie linie podziału. Można tu wyodrębnić studia ukierunkowane historycznie oraz współcześnie; ponadto widać specjalizację z jednej strony w dziedzinach analizy ekonomicznej i instytucjonalnej, a $z$ drugiej w etnograficznym opisie świata produkcji ${ }^{3}$. Produkcyjne badania historyczne pojawiały się już znacznie wcześniej, nie zawsze występując jednak pod jasno zadekretowanym szyldem production studies. Klasyczną pracą jest The Genius of the System: Hollywood Filmmaking in the Studio Era Thomasa Schatza ${ }^{4}$. Ostatnie dokonania z tej dziedziny, takie jak monografie studiów United Artists i MGM, można postrzegać jako rozwinięcie podejścia zaprezentowanego przez Schatza ${ }^{5}$.

W dokonaniach tych uwydatnia się mniej dotąd eksploatowany ,gatunek” pisarstwa filmoznawczego - monografia studia produkcyjnego bądź wytwórni. Bywa on z powodzeniem uprawiany w Europie, o czym świadczy monografia praskiego studia Barrandov lat 1945-1970 Petra Szczepanika ${ }^{6}$ czy rozpoczęty niedawno szeroko zakrojony i poświęcony brytyjskim, francuskim, niemieckim oraz włoskim studiom filmowym lat 1930-1960 projekt badawczy Sarah Street ${ }^{7}$. Na rodzimym gruncie godna uwagi jest monografia Wytwórni Filmów Oświatowych autorstwa młodych filmoznawców łódzkich: Michała Dondzika, Krzysztofa Jajko oraz Emila Sowińskiego ${ }^{8}$. Z młodszego pokolenia na uwagę zasługuje także środowisko gdańskie, skupione wokół Pracowni Badań Produkcyjnych i Nowej Historii Kina (Grzegorz Fortuna, Krystyna Weiher-Sitkiewicz, Joanna Kiedrowska, Paulina Pohl), zwłaszcza wyrosłe z niego prace poświęcone historii włoskiego kina popularnego oraz kulturze VHS w kontekście polskiej transformacji ${ }^{9}$.

\section{3.}

Za związane z badaniami produkcyjnymi uznaje się studia nad dystrybucją (w profesjonalnej kinematografii kampanie marketingowe rozpoczyna się przecież jeszcze przed rozpoczęciem zdjęć). Pod pojęciem tym rozumiemy instytucjonalną organizację oglądania, dla której centralnym zagadnieniem jest kształtowanie polityki repertuarowej (motywowanej także wymogami ideologicznymi) oraz warunków dostępu do oferty filmowej, a zatem: rozpowszechnianie (zakup licencji, decyzja o liczbie kopii czy ekranów premierowych, przygotowanie materiałów promocyjnych) i eksploatacja (geografia kin, statystyka emisji telewizyjnych, dostępność na nośnikach wtórnych). 
Empiryczne badania dystrybucji nie dotyczą jedynie „tu i teraz”, ale też pomagają zrozumieć historię kina - jako miejsca i instytucji. Zagadnienia te - w kontekście grawitującym w stronę badań widowni - były w Europie Zachodniej chętnie podejmowane przez badaczy z Niemiec, poznanych już dzięki polskim przekładom (Martin Loiperdinger, Joseph Garncarz), a także filmoznawców z Wielkiej Brytanii (John Sedgwick, Peter Krämer, Daniela Gennari-Trevari), Flandrii i Holandii (Daniël Biltereyst, Philippe Meers, Clara Pafort-Overduin, Lies Van de Vijver). Wspólną cechą tych badań jest, po pierwsze, ogniskowanie zainteresowania na kulturze rodzimej - narodowej i lokalnej. Nie oznacza to zamykania się w granicach własnych ojczyzn (małych czy dużych), bowiem coraz częściej międzynarodowe zespoły przygotowują prace komparatystyczne ${ }^{10}$. Po drugie, punktem wyjścia do badań recepcji (przez kwerendy prasowe czy historie mówione) są zazwyczaj skrupulatnie przygotowywane bazy danych z repertuarami kin. W Europie historycznie pierwsza była - zainicjowana przez Karla Dibbetsa, postać w tym środowisku niemalże kultową - baza holenderska powstała w 2005 r. i do dziś rozwijana; zawiera ona dane o programach kin (a także o ich reklamie i cenzurze) w holenderskich miastach do 1960 r. ${ }^{11}$. Po niej pojawiły się kolejne, w tym dwie dotyczące Brna, koordynowane przez Pavla Skopala ${ }^{12}$. Dane repertuarowe służą do badań statystycznych - od najprostszych (odnoszących się, na przykład, do liczby seansów danego filmu), po bardziej złożone, często z użyciem metody POPSTAT. Ta matematyczna formuła - uwzględniająca ,wagę kina” (na podstawie danych o przychodach oraz liczbie miejsc), „wagę filmu” (premierowy/powtórkowy), a także, w najnowszej wersji algorytmu, ,wagę dnia” - daje przybliżone dane na temat popularności filmów, szczególnie ciekawe w odniesieniu do tych rynków, dla których nie dysponujemy danymi typu box-office ${ }^{13}$.

Historia dystrybucji filmowej w Polsce to obszar w zasadzie nadal dziewiczy. Owszem, w rodzimym piśmiennictwie ostatnich lat pojawiło się kilka prac dokumentujących lokalne czy regionalne kultury filmowe, ale wciąż jest ich zbyt mało, zwłaszcza że dotyczą głównie okresu sprzed 1945 r. ${ }^{14}$. Natomiast w odniesieniu do kultury filmowej PRL polskie filmoznawstwo powinno się zdobyć na samokrytykę. Dlaczego akronimy takie, jak GDFP, OPRF i CWF oraz pojęcia Filmowa Rada Repertuarowa czy „pula specjalna” tak rzadko pojawiają się na kartach rozmaitych „historii kina polskiego"? Dlaczego o dystrybucji filmowej w państwach „demokracji ludowej” pisali dotąd w obiegu międzynarodowym tylko Czesi i Węgrzy? Czy polskie doświadczenia w tym zakresie - w tym fenomen Dyskusyjnych Klubów Filmowych, kin studyjnych i Konfrontacji - nie są warte uwagi?

4.

Dziś widownia chce w domowym zaciszu delektować się filmami „w zasięgu kciuka" - nie z telewizji ani nagranych na DVD czy Blu-ray, ale z wirtualnych wypożyczalni. Dotyka to przede wszystkim właśnie telewizji, czego dowodem jest zmiana znaczenia przypisywanego terminowi „strumień”. Metafora „wodna” (strumień obrazów niepodległych decyzji widza i z siłą wodospadu „wylewających się” nań) została zastąpiona metaforą „laserową” (kierunkowe pasmo danych). A przecież początki VOD były bliższe kategorii „biblioteki” (dla części badaczy jest oczywiste, że polem doświadczalnym dla VOD była internetowa pornografia) niż „strumienia”, natomiast korzystanie z tej technologii odsyłało do praktyki oglądania 
filmów na VHS czy DVD (kluczowa decyzja o „załadowaniu” konkretnego filmu czy serialu). Model AVOD (bez abonamentu, ale z reklamami) byłby zarazem bliższy dyspozytywowi telewizji niż SVOD (płatna subskrypcja). Ale i to się zmienia - jeszcze rok temu po włączeniu Netflixa na ekranie powitalnym pojawiały się po prostu ikonki dostępnych filmów i seriali, dziś - samoczynnie, bez woli użytkownika - trailer polecanego produktu.

Jeśli przywołaliśmy konkretną nazwę (medium? usługi? stylu życia?) to dlatego, że Netflix stał się symbolem przemian współczesnej dystrybucji. Już teraz zmierza on w kierunku modelu jednoznacznie globalnego ${ }^{15}$, generującego - podobnie jak konglomeraty medialne typu Disney - znacznie więcej zysków na innych rynkach niż na tzw. domestic (USA i Kanada). Kulturowy wymiar tych przemian wiąże się z nowym podziałem geograficznym świata, w którym dostęp do treści będzie warunkowany przez ponadnarodowe blokowanie (geoblocking) lub wewnętrzną cenzurę treści. Pisał o tym Ramon Lobato ${ }^{16}$ - kto wie, czy nie najważniejszy autor współczesnych studiów nad produkcją i dystrybucją filmową. To dzięki niemu ${ }^{17}$ tematyka piractwa przestała być postrzegana jako zagadnienie stricte prawne czy ekonomiczne i weszła na obszar zainteresowań studiów kulturowych, wyczulonych na kwestie relacji pomiędzy grupami dominującymi i marginalizowanymi (a zatem także na zagadnienia imperializmu - wyzysku ekonomicznego i manipulacji symbolicznej). Zamieszczony w niniejszym numerze fragment jego najnowszej książki Netlifix Nations (wydanej ledwie parę miesięcy temu, w 2019 r.) jest pierwszym - oby nie ostatnim - przekładem na język polski prac tego wciąż zbyt słabo znanego u nas autora.

Jeśli mówimy o silnie postępującej ,amerykanizacji” czy szerzej globalizacji współczesnej kultury audiowizualnej, to dotyczy ona głównie instytucji nadawczych oraz infrastruktury. Sektor dystrybucji jeszcze w latach 90. był znacznie bardziej zdecentralizowany - bo składała się na niego większa liczba podmiotów dysponujących prawami do treści ${ }^{18}$, licencjobiorców kupujących te prawa na dane terytorium, oraz wielu operatorów końcowych ogniw (w Polsce - tysiące ,panów Zbyszków” prowadzących osiedlowe wypożyczalnie kaset wideo). Dziś mamy do czynienia z zassaniem większości tych ogniw do centralnego ,płucoserca”, z którego prowadzą tętnice i żyły, czyli sieć przesyłowa danych. Nic więc dziwnego, że coraz częściej przedstawiciele branży mówią o połączeniu technologii nadawczych (broadcast) oraz szerokopasmowych (broadband). A właśnie od kondycji finansowej oraz technicznej tych „rurociągów” zależy dziś bardzo wiele.

Badania współczesnej dystrybucji filmowej najczęściej przybierają postać użytkowych, bieżących raportów o sektorze audiowizualnym, zamawianych zarówno przez instytucje publiczne, jak i prywatnych przedsiębiorców. Niekiedy dostarczają one istotnej wiedzy, której nie daje świat akademii. W kontekście rodzimym może być przedmiotem zadumy powód, dla którego rewolucja VOD jest tak niechętnie badana przez filmo- i medioznawców. Mówimy przecież o fenomenie masowym - według danych za IV kwartał 2018 r. Netflix miał w Polsce 775 tys. aktywnych subskrybentów ${ }^{19}$. Szczegółowe dane dotyczące widowni są pilnie strzeżonymi tajemnicami handlowymi. Według raportu Parrot Analytics z czerwca 2018 r. ${ }^{20}$ specyfiką polskiego rynku jest wysoki udział telefonów komórkowych w odbiorze treści telewizyjnych oraz niechęć do dubbingu aktorskich filmów dla dorosłych. Jak widać, kategoria narodowości ma istotne znaczenie nie tylko w analizach teks- 


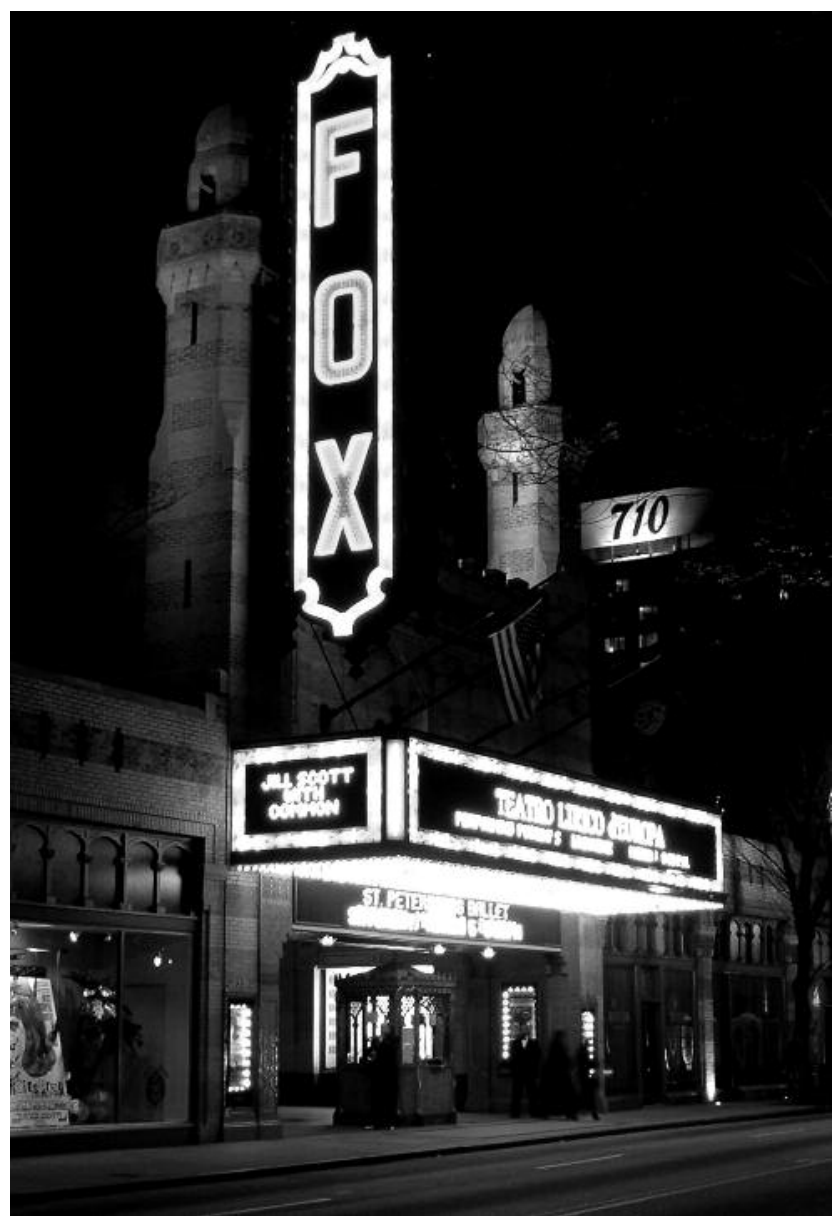

Kinoteatr Fox w sobotni wieczór, Atlanta w stanie Georgia, USA 2005

fot. Scott Ehardt

tualnych oraz badaniach produkcji, ale też w kontekście trybów dystrybucji oraz sposobów oglądania.

Język, którym się posługujemy, pisząc o dystrybucji filmów w Internecie, dopiero się kształtuje. W przypadku kina sprawa była w miarę prosta (od dystrybutora, po kiniarza), w wypadku telewizji może jeszcze prostsza (emisja w strukturze ramówki). W wypadku VOD mówimy już raczej o ,udostępnianiu treści”, którego tryb oscyluje pomiędzy praktykami telewizyjnymi. Umownie rzecz ujmując, mamy obecnie do czynienia z „modelem Netflixa”, który jest bardziej platformą sieciową, oraz „modelem HBO”, który wyrósł z telewizyjnych praktyk emisyjnych. Jeszcze niedawno wyrazilibyśmy przypuszczenie, że w dalszej przyszłości model HBO będzie wypierany, tj. że przyzwyczajenia widzów będą się kierowały w stronę myślenia o „bibliotece”, do której ma się ciągły dostęp, a nie o „przesyłce”, na którą trzeba czekać. Nieprzypadkowo współczesny model konsumpcji mediów zmierza do formuły instant access, która wzmacnia egoistyczną roszczeniowość i niestety, osłabia cnotę cierpliwości. Niebagatelny wpływ na utrwalenie postaw odbiorczych, 
zwłaszcza wśród młodego pokolenia, będzie miała zapewne platforma Disney+. Wydaje się, że wybrała ona „model HBO” (serial Mandalorian jest udostępniany stopniowo). Prawdopodobne jest zatem, że dojdzie do dywersyfikacji modeli dostępu do treści, tj. w podstawowym pakiecie na kolejny odcinek trzeba będzie poczekać, ale dodatkowa opłata otworzy dostęp do całości.

Sam windowing - kluczowe dla dystrybucji pojęcie oznaczające decyzję, kiedy film będzie dostępny w jakich mediach - także się zmienia. Jeszcze na początku XXI w. panował w tym względzie porządek: najpierw kina zeroekranowe, potem pozostałe, DVD i płatna telewizja, w końcu emisje na ,zwykłych” stacjach. Natomiast dla dzisiejszych obiegów charakterystyczne jest radykalne zmniejszenie (a w przywołanych wypadkach zniesienie) „bufora” pomiędzy premierą kinową a VOD. Niekiedy zmiany przybierają nieoczekiwany obrót: pod koniec $2019 \mathrm{r}$. media obiegła informacja, że Netflix otwiera swoje pierwsze kino na Manhattanie. Możliwe, że jest to tylko PR-owy zabieg towarzyszący kampanii promocyjnej Irlandczyka Martina Scorsesego (wcześniejszą parakinową produkcją Netflixa była Roma Alfonsa Cuarona). Może też być to wybieg prawny, mający zabezpieczyć produkcje filmowe Netflixa przed regulaminowymi zapisami festiwali, które nie dopuszczają do konkursu produkcji telewizyjnych, tj. nieprzeznaczonych do emisji w kinie (wiosną 2018 r. dyrektor festiwalu w Cannes, Thierry Fremaux, ogłosił, że filmy Netfliksa nie będą się mogły ubiegać o Złotą Palmę). Choć nie należy spodziewać się masowego powstawania „kin Netflixa”, samo kino - jako instytucja nadal jest ważnym ogniwem w machinie dystrybucyjnej. W wypadku pełnometrażowych filmów fabularnych jest wręcz jej kołem zamachowym. Studia filmowe niechętnie dzielą się danymi o sprzedaży DVD czy o kwotach pozyskanych od nadawców telewizyjnych lub operatorów VOD, ale ochoczo podają do wiadomości kinowy box-office. Dystrybutorzy chwalą się, że na rynku FMCG (fast moving consumer goods) są jedyną branżą, która tak chętnie ujawnia dane sprzedażowe, sporo w tym jednak kokieterii i kalkulacji, bowiem box-office to przede wszystkim część kampanii marketingowej, która ma służyć promocji filmu na kolejnych etapach życia dystrybucyjnego.

5.

Nieodłączną częścią pisania o współczesnej produkcji i dystrybucji filmowej są przypuszczenia dotyczące jej kolejnych transformacji. Ponieważ niniejsze wprowadzenie już za parę miesięcy zyska walor dokumentu historycznego, pozwalamy sobie na podobną quasi-akademicką zabawę.

Linie rozwoju produkcji filmowej rysują się wyraźnie i jeśli nie są tylko mirażem, powinny jeszcze silniej podlegać postępowi technologii cyfrowej. Jej wpływ jest wieloaspektowy i oddziałuje zarówno na korporacyjnie wytwarzane blockbustery, jak również na oddolną działalność amatorów filmowych. Technologia jest dziś tak tania i dostępna, jak nigdy wcześniej, ale upowszechnia się także dostęp do wiedzy filmowej. Korzystając z materiałów łatwych do odnalezienia w sieci, będzie można zdobywać rzemieślniczy fach filmowy bez wieloletniej edukacji na uczelni artystycznej. Twórczość ulegnie dalszej demokratyzacji, a trudnością dla filmowców nie będzie już zdobycie środków na realizację filmu bądź samo jego kręcenie, lecz przede wszystkim odnalezienie swojego miejsca w sieciach rozpowszechniania w dobie audiowizualnej nadprodukcji. Dobrem, o które się konku- 
ruje, okaże się uwaga konsumentów. Niewykluczony jest renesans formy krótkiej, inscenizowanej w taki sposób, by była wygodna do docelowego wyświetlania jej na ekranach telefonów. Technologia cyfrowa coraz silniej będzie też oddziaływać na proces produkcyjny w strukturach hollywoodzkich konglomeratów. Idzie tu nie tylko o efekty specjalne, ale także cyfrowe symulacje jako element procesu kreacji produktu filmowego, rozmaite prewizualizacje, przymiarki do filmowego designu i moodboardy. Już teraz dostrzegalny jest trend, by projekt oceniać i decydować o skierowaniu go do produkcji nie tylko na podstawie linearnego, zapisanego scenariusza, ale zrealizowanych wybranych scen, trailerów, prezentacji czy właśnie moodboardów. Jeśli prawdziwe są diagnozy Jacka Dukaja piszącego o wchodzeniu $\mathrm{w}$ erę postpiśmienności i prób pozapiśmiennego transferu przeżyć, to tego typu zjawiska chyba je potwierdzają ${ }^{21}$.

Przypuszczenia dotyczące sposobów dystrybucji filmu także są modelowane przez wyobrażenia przyszłości kultury cyfrowej. Z jednym wyjątkiem - na rynku kinowym rewolucja cyfrowa już się dokonała. Proroctwa o ,śmierci kina” (jako miejsca publicznego oglądania filmów) okazały się, nie pierwszy raz, mocno przesadzone - rynek ten wciąż rośnie, w Polsce zaś przynosi co roku większe zyski. Niewykluczone, że w najbliższej dekadzie kina będą się zmieniać w kierunku już dziś rozpoznanym: multipleksy będą silnie zintegrowane $\mathrm{z}$ centrami handlowymi, a kina studyjne $-\mathrm{z}$ instytucjami kultury i nauki. W pierwszym wypadku zmiana może dotyczyć większej liczby seansów nie w ciemności, a w półmroku, umożliwiającym na przykład konsumpcję posiłków innych niż popcorn (jak w podparyskim Disneylandzie). W drugim wypadku większą rolę będą odgrywać klastry edukacyjno-kulturalne (nowoczesne muzea czy „domy kultury 2.0”, umożliwiające bezpośredni kontakt z wiedzą); coraz częstszą strategią promowania seansów są spotkania z twórcami, szkolenia czy działania edukacyjne.

Zmiany, jakie czekają filmoznawstwo akademickie, będą przypuszczalnie związane z jeszcze silniejszym ,zwrotem empirycznym”. Ma on konsekwencje także dla dydaktyki. Do niedawna absolwent studiów filmoznawczych, który w dalszej edukacji nie otarł się o szkołę filmową, najpewniej nie znał formatu scenariusza, nie wiedział, czym jest kalendarzówka ani jak rozszyfrować skrót P\&A. Dziś zagadnienia te nie muszą być już przemycane do siatek studiów, lecz coraz częściej stanowią ich integralną część (co jest, na razie, szczególnie widoczne na Uniwersytecie Łódzkim oraz Uniwersytecie Gdańskim, na którym w 2019 r. otwarto nowy kierunek o nazwie „Produkcja form audiowizualnych”, mający kształcić studentów konkurencyjnych względem absolwentów produkcji w szkołach filmowych). Wprowadzanie do programu takich kompetencji nie musi służyć wyłącznie „odhaczeniu” przesadnie dziś zresztą fetyszyzowanej tzw. współpracy z biznesem. To przecież umiejętności, które powinny być - i coraz częściej faktycznie są - ujawniane przez historyków i teoretyków filmu, czego dowodem są także prace zawarte w niniejszym numerze.

Marcin Adamczak, Konrad Klejsa 


\section{WSPÓkCZESNE BADANIA PRODUKCJI I DYSTRYBUCJI...}

${ }^{1}$ W Państwowej Wyższej Szkole Filmowej, Teatralnej i Telewizyjnej w Łodzi zrealizowano dwa granty zespołowe: „Współczesna Łódź Filmowa: badania lokalnej kultury produkcji i widowni filmowej" (2011-2015; Narodowe Centrum Nauki, kierownik Konrad Klejsa) i „Proces tworzenia dzieła filmowego oraz jego uwarunkowania organizacyjno-ekonomiczne w perspektywie badań kultury produkcji” (2016-2019, Narodowy Program Rozwoju Humanistyki, kierownik Marcin Adamczak). Obecnie na Uniwersytecie Lódzkim jest realizowany projekt „Rozpowszechnianie filmów w Polsce w latach 1945-1989" (Narodowe Centrum Nauki, kierownik: Konrad Klejsa). ${ }^{2}$ Zob. M. Adamczak, Kapitaty przemystu filmowego: Hollywood, Europa, Chiny, PWN, Warszawa 2019; T. Kożuchowski, I. Morozow, R. Sawka, Spoleczny wymiar tworzenia filmu $w$ Polsce, Wydawnictwo PWSFTviT, Łódź 2019; A. Majer, A. Orankiewicz, A. Wróblewska, Pieniądze - produkcja - rynek. Finansowanie produkcji filmowej w Polsce, Wydawnictwo PWSFTviT, Łódź 2019; M. Adamczak, K. Klejsa, Badanie dystrybucji filmowej - pola problemowe, stan wiedzy, perspektywy rozwoju, w: Wokól zagadnień dystrybucji filmowej, red. M. Adamczak, K. Klejsa, Wydawnictwo PWSFTviT, Łódź 2015; K. Klejsa, M. Saryusz-Wolska, Badanie widowni filmowej: historia $i$ metody, w: Badanie widowni filmowej. Antologia przekładów, red. K. Klejsa, M. Saryusz-Wolska, Scholar, Warszawa 2014.

${ }^{3}$ Ten podział dobrze widać na przykładzie komplementarnych książek powstałych jako efekt wspomnianego grantu NPRH: T. Kożuchowski, I. Morozow, R. Sawka, dz. cyt., oraz A. Orankiewicz, A. Majer, A. Wróblewska, dz. cyt.

${ }^{4}$ T. Schatz, The Genius of the System: Hollywood Filmmaking in the Studio Era, Univeristy of Minnesota Press, New York 1988.

${ }^{5}$ T. Balio, $M G M$, Routledge, New York 2018; United Artists, red. P. Krämer, G. Needham, Y. Tzioumakis, T. Balio, Routledge, New York 2020.

${ }^{6}$ P. Szczepanik, Továrna Barrandov. Svět filmařu a politická moc 1945-1970, NFA, Praha 2016.

7 Zob. http://www.bristol.ac.uk/film/news/2019/sarah-street-erc-grant.html (dostęp: 20.12.2019).

${ }^{8}$ M. Dondzik, K. Jajko, E. Sowiński, Elementarz Wytwórni Filmów Oświatowych, WFO, Łódź 2018. Zob. także inne publikacje E. Sowińskiego opublikowane na łamach „Kwartalnika
Filmowego": Idea studia dla młodych filmowców. Studio Munka - powstanie, działalność i produkcyjny dialog z przeszłościa, „Kwartalnik Filmowy" 2018, nr 103, s. 54-64.; tegoż, Finansowanie ,,amerykańskich filmów polskich" w świetle badań archiwalnych. Przypadek Władysława Pasikowskiego, „Kwartalnik Filmowy" 2019, nr 105-106, s. 39-55.

${ }^{9} \mathrm{G}$. Fortuna, W krainie imitacji. Gialli i horrory na tle wtoskiego kina popularnego lat 80., w: Kino włoskie po 1980 roku, red. A. Miller-Klejsa, D. Dąbrowska, Wydawnictwo UŁ, Łódź 2018; tegoż, Rynek wideo w Polsce, „Images. The International Journal of European Film, Performing Arts and Audiovisual Communication" 2013, t. XIII, nr 22.

${ }^{10}$ Zob. D. Biltereyst, P. Meers, New Cinema History and the Comparative Mode: Reflections on Comparing Historical Cinema Cultures, „Alphaville. Journal of Film and Screen Media" 2016, nr 11.

11 Zob. http://www.cinemacontext.nl (dostęp: 20.12. 2019).

12 Projekt dotyczący lat 1918-1945, zob. https://www.phil.muni.cz/filmovebrno) oraz okresu 1945-1989, zob. (https://www.phil.muni.cz/dedur). Z ostatnich anglojęzycznych prac Skopala warto wymienić: P. Skopal, Going to the Cinema as a Czech: Preferences and Practices of Czech Cinemagoers in the Occupied City of Brno, 1939-1945, „Film History” 2019, t. 31, nr 1; P. Skopal, K. Kunakchovich, Cinema Cultures of Integration: Film Distribution and Exhibition in the GDR and Czechoslovakia from the Perspective of Two Local Cases, 1945-1960, w: Cinema in Service of the State: Perspectives on Film Culture in the GDR and Czechoslovakia 1945-1960, red. P. Skopal, L. Karl, Berghahn, New York - Oxford 2015. ${ }^{13} \mathrm{~W}$ jęz. polskim zob. przekład: J. Sedgwick, C. Pafort-Overduin, Znajomość zachowań widowni na podstawie danych statystycznych: Londyn i Amsterdam w polowie lat 30. XX wie$k u$, tłum. A. Cybulski, M. Rawska, w: Filmowa Europa: dawniej $i$ dziś, red. M. Pabiś-Orzeszyna, M. Rawska, P. Sitarski, Wydawnictwo UŁ, Łódź 2019. Jedynym jak dotąd polskim autorem, który zastosował założenia POPSTAT we własnej pracy badawczej, jest Andrzej Dębski (zob. tegoż, Nowoczesność, rozrywka, propaganda. Historia kina we Wroclawiu w latach 1919-1945, Atut, Wrocław 2019).

${ }^{14} \mathrm{Z}$ ostatnich lat, poza Dębskim, trzeba wymienić: K. Trojanowski, Świnie $w$ kinie. Film w okupowanej Polsce, PWN, Warszawa 2018; W. Świdziński, Co było grane? Film zagra- 
niczny $w$ Polsce $w$ latach 1918-1929 na przykładzie Warszawy, Wydawnictwo ISPAN, Warszawa 2015.

${ }^{15}$ Według danych spółki (https://www.netflixinvestor.com/financials/quarterly-earnings/default.aspx (dostęp: 20.12.2019) we wrześniu 2019 r. Netflix miał niemal 158,5 mln stałych użytkowników na całym świecie (wprawdzie w II kwartale tego roku okazało się, że w USA stracił w odniesieniu do poprzedniego kwartału 130 tys. subskrybentów, ale na świecie zyskał niemal 3 mln nowych klientów).

${ }^{16}$ R. Lobato, J. Meese, Geoblocking and Global Video Culture, Institute of Network Cultures, Amsterdam 2016; R. Lobato, Netflix Nations, NYU Press, New York 2019.

${ }^{17}$ Zob. R. Lobato, Shadow Economies of Cinema. Mapping Informal Film Distribution, BFI, London 2012; R. Lobato, J. Thomas, The Informal Media Economy, Polity, Cambridge 2015.

${ }^{18}$ Netlfix ma prawa do niewielu filmów i seriali, prym wiodą tu trzy o wiele większe korporacje. Po pierwsze: Disney, który po wchłonięciu Foxa stał się potęgą i oprócz platformy sygnowanej własnym logo prowadzi też w Ameryce Północnej serwis Hulu. Po drugie, NBC-Universal, która prowadzi prace nad własnym systemem streamingowym Peacock. Po trze- cie, Warnermedia, w skład którego wchodzi też HBO. W tej konkurencji pozycja wyjściowa Netlifixa, jeśli chodzi o treści, jest słabsza - stąd poszukiwania sojuszników, niekiedy nieoczekiwanych (w Polsce w najnowszej ofercie platforma $\mathrm{Nc}+$ oferuje właśnie dostęp do do Netflixa) oraz gigantyczne inwestycje. Niekiedy mówi się wprost o wojnach streamingowych między platformami - przed laty przecieraliśmy oczy ze zdumienia, słysząc o wydaniu przez Netflix 100 mln dolarów na prawa do serialu Przyjaciele, dziś słyszymy o kwocie pięciokrotnie większej za serial Seinfeld.

${ }^{19} \mathrm{http}$ ://screenlovers.pl/o-polskich-subskrypcjach-z-serialami-w-tle-raport-z-frontu-svod/ (dostęp: 20 grudnia 2019). Więcej miała tylko Ipla.pl (najstarszy serwis w Polsce, związany z Cyfrowym Polsatem i Plusem) - 1,17 mln subskrybentów. W połowie listopada 2019 r. rynek obiegła wiadomość, że Polsat (ipla.pl) i TVN (player.pl) mają połączyć siły i stworzyć nowy serwis VOD, oferujący treści obu nadawców.

${ }^{20}$ Zob. https://www.parrotanalytics.com/insights/poland-television-demand-measurementfor-svod-and-ott/ (próba 5 tys. osób; dostęp: 20.12.2019).

${ }^{21}$ J. Dukaj, Po piśmie, Kraków 2019. 